\title{
Metals as Catalysts during the Formation and Decomposition of Chlorinated Dioxins and Furans in Incineration Processes
}

\author{
Kees Olie, Ruud Addink, and Mirjam Schoonenboom \\ Department of Environmental and Toxicological Chemistry, Amsterdam Research Institute for Substances \\ in Ecosystems, University of Amsterdam, Amsterdam, The Netherlands
}

\begin{abstract}
Polychlorinated dibenzo- $p$-dioxins (PCDDs) and polychlorinated dibenzofurans (PCDFs) are found on fly ash and in flue gas of municipal waste incinerators. Municipal waste incinerators seem to be the most important source for PCDDs and PCDFs emitted into the air during the last decades. PCDD/F formation takes place in the cooler zones $\left(250^{\circ} \mathrm{C}-450^{\circ} \mathrm{C}\right)$ of a municipal waste incinerator, at the electrostatic precipitator. Copper is an important component of the fly ash that can catalyse the formation of PCDDs and PCDFs. Inhibition of the formation can be done by complexation of the metals $(\mathrm{Cu})$ with EDTA or NTA.
\end{abstract}

\section{INTRODUCTION}

\section{Properties of PCDDs and PCDFs}

Polychlorinated dibenzo-p-dioxins (PCDDs) and polychlorinated dibenzofurans (PCDFs) are a group of tricyclic compounds substituted with one to eight chlorine atoms. This results in 210 different compounds: 75 PCDDs and 135 PCDFs. Seventeen congeners are more toxic than the others. These toxic congeners all have chlorine atoms at the 2,3,7 and 8 positions. PCDDs and PCDFs are very stable compounds and have very long residence times in the environment and in organisms, including humans. Their hydrophobicity promotes accumulation in sediments and organisms, resulting in high concentrations in both sediment and organisms. Physical chemical properties of PCDDs and PCDFs are reported in Table 1 . In a substantial number of studies the effects of PCDDs and PCDFs on various animals are determined. Among toxicological effects reported are teratogenicity, reduced reproduction, liver toxicity, decreased growth rate and behavioral changes. ${ }^{1}$ Toxicological effects were also reported for humans: chloracne, enlargement and tenderness

\section{IMPLICATIONS}

PCDDs and PCDFs are very toxic compounds that can enter the foodchain after being emitted into the air. Because of the toxicity, emission levels are set as low as $0.1 \mathrm{ng} \mathrm{TEQ} / \mathrm{m}^{3}$ for waste incinerators. of the liver, decreased libido or sexual dysfunction, personality changes, tiredness, hirsutism, and neurological disorders. ${ }^{2}$ Some studies also suggested soft tissue sarcoma, stomach cancer, nasal cancer, and cancer of the respiratory tract. In other studies of these cancers, no correlation was found. ${ }^{2}$

\section{Sources}

PCDDs and PCDFs have never been produced intentionally, but are formed as trace contaminants in various processes. One of the first known sources was in the production of 2,4,5-T, a herbicide. The production of pentachlorophenol has also been long established as a source. Restrictions to production have eliminated these sources to a large extent, at least in some countries. Sources of PCDD/F emission into the air are reported in Table 2. Municipal waste incineration is responsible for most of the PCDDs and PCDFs emitted into the air during recent decades. ${ }^{4,5}$ In 1977 , they were found on fly ash and in the flue gas of municipal waste incinerators. ${ }^{6}$ Related compounds, like chlorobenzenes and chlorophenols, were also found. New technologies of flue gas cleaning in waste incineration will reduce the amount of PCDD and PCDF in the flue gas and, therefore, the contribution of municipal waste incineration in PCDD/F emission into the air. The total amount of PCDD and PCDF formed can be reduced by using filter systems that work at higher or lower temperatures than the optimum temperatures for the formation of PCDD/Fs. Waste from the cleaning section contains the larger part of the
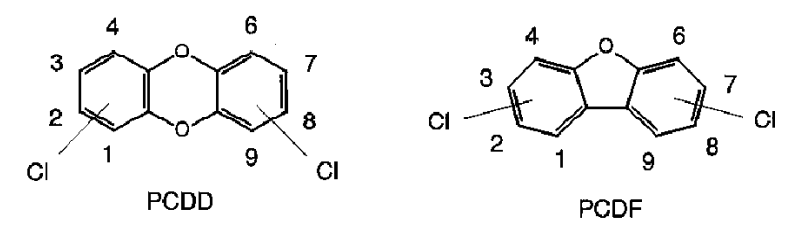

Figure 1. Molecular structures of PCDD and PCDF. 
Table 1. Some physical chemical properties. ${ }^{3}$

\begin{tabular}{|c|c|c|c|c|c|c|c|c|c|}
\hline & $\begin{array}{l}\mathrm{MP}^{\mathrm{b}} \\
\left({ }^{\circ} \mathrm{C}\right)\end{array}$ & $\begin{array}{l}\mathrm{BP}^{\mathrm{c}} \\
\left({ }^{\circ} \mathrm{C}\right)\end{array}$ & $P^{s d}(P a)$ & $\begin{array}{c}S^{e} \\
\left(m g / m^{3}\right)\end{array}$ & $\log K_{\text {ow }}{ }^{f}$ & $\begin{array}{c}\text { Half Life } \\
\quad \text { Air }\end{array}$ & $\begin{array}{c}\text { Half Life } \\
\text { Water }\end{array}$ & $\begin{array}{c}\text { Half Life } \\
\text { Soil }\end{array}$ & $\begin{array}{l}\text { Half Life } \\
\text { Sediment }\end{array}$ \\
\hline $\operatorname{PCDDs}^{\mathrm{a}}$ & 89- 322 & $284-510$ & $1.1^{*} 10^{-10}-0.017$ & $74^{*} 10^{-6}-417$ & $4.3-8.2$ & 2 days- 3 weeks & 2 days- 8 months & 2 months- 6 years & 8 months- 6 years \\
\hline $\mathrm{PCDFs}^{\mathrm{a}}$ & $184-258$ & $375-537$ & $5^{\star} 10^{-10}-3.9^{\star} 10^{-4}$ & $1.16^{\star} 10^{-3}-14.5$ & $5.4-8.0$ & 1 - 3 weeks & 3 weeks- 8 months & 8 months- 6 years & $2-6$ years \\
\hline
\end{tabular}

${ }^{a}$ Range for mono- to octa-chlorinated congeners, ${ }^{b} \mathrm{MP}=$ melting point, ${ }^{\mathrm{c}} \mathrm{BP}=$ boiling point, ${ }^{\mathrm{d}} \mathrm{P}^{\mathrm{s}}=$ vapour pressure, ${ }^{\mathrm{e}}=$ solubility, ${ }^{\mathrm{f}} \mathrm{Kow}_{\text {ow }}=$ octanol water partition coefficient.

PCDD/Fs formed.

Most of the reported PCDD/F sources are high-temperature processes. In addition to waste incineration, these include iron ore sintering in the steel industry, ${ }^{7}$ aluminium recycling, ${ }^{8}$ copper ore melting, ${ }^{9}$ nickel refinery, magnesium production, ${ }^{10}$ electrical cable splicing, ${ }^{11}$ catalyst regeneration in the petroleum refining industry, ${ }^{12}$ fossil-fueled powerhouses, ${ }^{13}$ automobile exhausts, ${ }^{13,14}$ fireplaces, charcoal grills, and cigarettes. ${ }^{13}$ Slag from copper ore melting was used at one time as covering material for sportsgrounds and playgrounds, ${ }^{9}$ resulting in PCDD/PCDF contamination of these areas.

Although not reported in Table 2, pulp bleaching in the paper industry is a source of PCDD/Fs in other countries. ${ }^{15-19}$ From the chemical production processes, the production of chlorophenols is the most important one; ${ }^{20-22}$ it leads to PCDD/F contamination in wood impregnated with pentachlorophenol, ${ }^{22}$ and to contamination of chemicals formed from chlorophenols, like 2,4,5-T (2,4,5trichlorophenoxy acids). ${ }^{20}$ Other chemical production processes reported as sources of PCDDs and PCDFs are the production of chlorobenzenes, chlorobi-phenyls, ${ }^{21}$ chlorobenzoquinones, ${ }^{24}$ and dyes (phthalocyanines and dioxazines). ${ }^{25}$

PCDD/F formation during any natural or human activity requires three basic ingredients: an organic starting material, a chlorine source, and, in processes with relatively low temperatures, a metallic catalyst. These compounds can be present in different amounts; the metallurgic industry,

Table 2. Emissions of PCDDs and PCDFs in The Netherlands (g TEQ/year), 1991. ${ }^{4}$

\begin{tabular}{lr}
\hline \hline Municipal solid waste incineration & 382 \\
Other incineration processes & 18.4 \\
Burning of cables and electromotors & 1.5 \\
Asphalt-mixing plants & 0.3 \\
Combustion of oil, coal, lignite and wood & 16.7 \\
Traffic & 7.0 \\
Sintering processes & 26 \\
Metal industry & 4.0 \\
Chemical production processes & 0.5 \\
Use of wood preservatives & 25 \\
Various high temperature processes & 2.9 \\
\hline \hline
\end{tabular}

for example, has high amounts of metals available, but low amounts of carbon and chlorine. In the paper industry, large amounts of chlorine and carbon are available, but low amounts of metals.

\section{MUNICIPAL WASTE INCINERATION Incineration Parameters}

The CO concentration in flue gas is an indicator of combustion conditions. $\mathrm{CO}$ also correlates to some extent with PCDD/F concentrations. ${ }^{26-28}$ Important parameters in CO control are oxygen concentration and furnace temperature. Excess oxygen and low furnace temperatures yield high $\mathrm{CO}$ and high PCDD/F concentrations. An oxygen concentration that is too low, however, will cause other problems, like formation of PAHs. ${ }^{29,30}$ Good control of oxygen is therefore very important. The residence time in the cooling section is also an important parameter. Long residence times means high $\mathrm{PCDD} / \mathrm{F}$ concentrations. The residence time in a small temperature window around $340{ }^{\circ} \mathrm{C}$ is very decisive. ${ }^{31} \mathrm{HCl}$, sulfur oxides, and nitrogen oxide concentrations in the flue gas do not correlate with the PCDD/F concentrations. Also, the percentage of moisture in the flue gas has no effect. ${ }^{28,32}$ Adding PVC to the feedstock will give higher $\mathrm{HCl}$ concentrations. As there is no correlation between $\mathrm{HCl}$ concentration and $\mathrm{PCDD} / \mathrm{F}$ concentration, this has no direct influence on the PCDD/F concentration. ${ }^{33}$ There is a correlation between the elemental composition of fly ash and PCDD/F concentrations. Chlorine, copper, sodium, potassium, and zinc have a positive correlation with PCDD/F concentration, with copper being the most effective. Aluminum and silicon have a negative correlation. ${ }^{34}$ In Table 3, the average concentration of some metals in fly ash from a large number of municipal waste incinerators is reported.

\section{Mechanism of Formation}

Since the discovery of PCDDs and PCDFs in Municipal Waste Incinerator (MWI) fly ash and flue gas in 1977, much attention has been paid to the formation of these compounds. Theoretical calculations by Shaub and Tsang showed that formation is unlikely to take place through homogeneous gas phase reactions. ${ }^{36,37}$ They instead proposed a heterogeneous fly ash catalyzed mechanism of formation in the 
Table 3. Average metal concentration in fly ash $(\mathrm{mg} / \mathrm{g}){ }^{35}$

\begin{tabular}{llll}
\hline \hline $\mathrm{Al}$ & 96 & $\mathrm{Cr}$ & 1 \\
$\mathrm{Ca}$ & 50 & $\mathrm{Cu}$ & 1 \\
$\mathrm{Fe}$ & 45 & $\mathrm{Ni}$ & 0.46 \\
$\mathrm{Zn}$ & 42 & $\mathrm{As}$ & 0.05 \\
$\mathrm{~Pb}$ & 9.3 & $\mathrm{Hg}$ & 0.02 \\
$\mathrm{Cd}$ & 2.3 & & \\
\hline \hline
\end{tabular}

post combustion zone of the incinerator. It was experimentally verified that the $\mathrm{PCDD} / \mathrm{F}$ concentration in the flue gas passing the downstream region before the electrostatic precipitator is very low. ${ }^{5,38}$ Since 1982, a large number of experiments have been performed in which the formation on fly ash has been modelled on laboratory scale. A review of the results is given by Addink and Olie. ${ }^{39}$

Chlorinated aromatic compounds can be intermediates in the formation of PCDDs and PCDFs. The correlation between some chlorinated compounds and PCDD/Fs present in a municipal waste incinerator support this route of formation. Chlorophenols, however, might play only a minor role in PCDD/F formation according to the lack of correlation between chlorophenols and PCDD/Fs in a municipal waste incineration. The isomer pattern found for the PCDD/Fs formed from chlorophenols during laboratory experiments also does not support the role of chlorophenols.

A rather good correlation between the chlorinated benzenes and PCDD/Fs is found. Chlorinated benzenes can be formed from benzene during model experiments, but it is not possible to form PCDD/Fs from benzene under realistic model conditions. ${ }^{40,41}$

Model experiments support the idea that carbon on the fly ash plays an important role during the formation of PCDD/Fs.

\section{MUNICIPAL WASTE INCINERATION FLY ASH AS A CATALYST FOR THE FORMATION OF PCDDS AND PCDFs}

Shaub et al. ${ }^{36}$ have calculated that homogeneous gas-phase formation of PCDDs and PCDFs from (chlorophenol) precursors is not likely to occur. They suggested a surface reaction where the fly ash surface can promote reactions at relatively low temperatures.

\section{Chlorination Reactions on Fly Ash}

Fly ash is known to catalyze chlorination of aromatic compounds such as toluene, biphenyl, diphenylether, PAHs, dibenzodioxin, and lower-chlorinated PCDD congeners. The products found point to an electrophilic aromatic substitution reaction. ${ }^{42-46}$ This electrophilic aromatic substitution reaction can also take place on model fly ash systems, like silica gel, activated carbon, Tenax GC polymer, and a silica-alumina support impregnated with copper chloride. ${ }^{47,48}$

\section{Dechlorination Reactions}

Fly ash is also able to catalyze the dechlorination of PCDDs and PCDFs. Heating fly ash in absence of oxygen leads to a decrease of PCDD/F concentration. This decrease is totally due to a decrease of higher chlorinated congeners, the amount of lower chlorinated congeners increases. This has led to the assumption that a dechlorination/hydrogenation reaction occurs under these reaction conditions, leading to the formation of lower chlorinated congeners. ${ }^{49-53}$

\section{Formation of PCDDs and PCDFs}

A third reaction catalyzed by fly ash is the formation of PCDDs and PCDFs. The amount of PCDDs and PCDFs increased when the fly ash was heated at temperatures around $300{ }^{\circ} \mathrm{C}$ in an oxygen atmosphere. ${ }^{49-51,54}$ PCDDs and PCDFs are in this case probably formed from residual carbon present on the fly ash surface. Ions of heavy metals or of the transition metal group are essential for this formation reaction. ${ }^{51}$ Copper has been identified as the strongest catalyst. ${ }^{50}$ The catalytic action of $\mathrm{CuCl}_{2}$ is poisoned by $\mathrm{NH}_{3}$, which results in lower $\mathrm{PCDD} / \mathrm{F}$ amounts in the presence of $\mathrm{NH}_{3}$. As already noted in the preceding section, the amount of oxygen present can influence the formation of PCDDs and PCDFs. Already 1\% oxygen present in the carrier gas causes formation of $\mathrm{PCDD} / \mathrm{Fs}^{60}$

\section{FORMATION OF PCDDS AND PCDFs FROM CARBON}

The molecular structure of carbon consists of layers of aromatic rings of the type existing in graphite. ${ }^{55}$ This ordered structure can be disturbed by oxygen and hydrogen atoms. ${ }^{56}$ Part of the layer can also contain aliphatic chains.

Formation of PCDDs and PCDFs from carbon starts with the chlorination of the surface of carbon. During oxidation of the carbon afterwards, PCDDs and PCDFs are released. The following knowledge is available on the mechanism of chlorination, the effect of water and carbon sources, temperature dependence, and inhibition with respect to the mechanism of formation of PCDDs and PCDFs.

\section{The Deacon Reaction}

Chlorination of aromatic ring structures with $\mathrm{HCl}$ is a thermodynamically unfavored reaction: chlorination of benzene $(\mathrm{Bz})$ with $\mathrm{HCl}$, for example, proceeds with a positive Gibbs free energy of formation. ${ }^{57}$

$\mathrm{Bz}(\mathrm{g})+2 \mathrm{HCl}(\mathrm{g}) \rightarrow \mathrm{Cl}_{2} \mathrm{Bz}(\mathrm{g})+\mathrm{H}_{2}(\mathrm{~g}) \quad \Delta \mathrm{G}=34.3 \mathrm{kCal}$

When $\mathrm{HCl}$ is first converted to $\mathrm{Cl}_{2}$ a favored reaction is obtained. 
$2 \mathrm{HCl}(\mathrm{g})+{ }_{-} \mathrm{O}_{2}(\mathrm{~g}) \rightarrow \mathrm{Cl}_{2}(\mathrm{~g})+\mathrm{H}_{2} \mathrm{O}(\mathrm{g}) \Delta \mathrm{G}=-9.07 \mathrm{kCal}$

$\mathrm{Bz}(\mathrm{g})+\mathrm{Cl}_{2}(\mathrm{~g}) \rightarrow \mathrm{Cl}_{2} \mathrm{Bz}(\mathrm{g}) \quad \Delta \mathrm{G}=-11.23 \mathrm{kCal}$

Reaction 2 can be catalyzed by copper, as can be seen in reaction $4{ }^{49}$

$$
\begin{gathered}
\mathrm{CuCl}_{2}+{ }_{-} \mathrm{O}_{2} \rightarrow \mathrm{CuO}+\mathrm{Cl}_{2} \\
\mathrm{CuO}+2 \mathrm{HCl} \rightarrow \mathrm{CuCl}_{2}+\mathrm{H}_{2} \mathrm{O} \\
2 \mathrm{HCl}+{ }_{-} \mathrm{O}_{2} \rightarrow \mathrm{Cl}_{2}+\mathrm{H}_{2} \mathrm{O}
\end{gathered}
$$

This reaction is called the Deacon Reaction and could play a role in the chlorination of carbon. ${ }^{49,50,57,58}$ The chlorine formed in the Deacon Reaction can react back to hydrogen chloride with sulfur dioxide (reaction 5). This reaction will inhibit the chlorination of carbon and, hence, the formation of PCDDs and PCDFs. ${ }^{57,58}$

$$
\mathrm{SO}_{2}+\mathrm{Cl}_{2}+\mathrm{H}_{2} \mathrm{O} \rightarrow \mathrm{SO}_{3}+2 \mathrm{HCl}
$$

\section{Chlorination via Direct Transfer}

Stieglitz et al. ${ }^{58}$ have looked at the influence of $\mathrm{HCl}$ and $\mathrm{SO}_{2}$ on the formation of PCDDs and PCDFs. When the Deacon reaction plays an important role in the formation of $\mathrm{PCDD} / \mathrm{Fs}, \mathrm{HCl}$ would stimulate the formation of PCDDs and PCDFs, and $\mathrm{SO}_{2}$ would inhibit PCDD/F formation. $\mathrm{HCl}$ and $\mathrm{SO}_{2}$ concentrations, however, were found to have no influence on the formation of PCDDs and PCDFs. Elemental chlorine gas without copper chloride does not yield PCDDs and PCDFs at $300{ }^{\circ} \mathrm{C}$. It also does not give oxidation of carbon at that temperature. ${ }^{58}$ In other studies, ${ }^{59}$ no correlation is found between the surface area of the carbon and the formation of PCDDs and PCDFs. This means that a direct interaction carbon-gas phase (as in the Deacon Reaction) is not the rate determining step. These facts suggest that the Deacon process plays only a minor role in the formation of PCDDs and PCDFs. Stieglitz et al. ${ }^{58}$ have proposed a mechanism of direct transfer of halogen instead.

$$
\begin{gathered}
\mathrm{ArH}+\mathrm{CuCl}_{2} \rightarrow \mathrm{ArHCl}^{*}+\mathrm{CuCl} \\
\mathrm{ArHCl}^{*}+\mathrm{CuCl}_{2} \rightarrow \mathrm{ArCl}+\mathrm{CuCl}+\mathrm{HCl}
\end{gathered}
$$

$\mathrm{Cu}(\mathrm{I})$ is oxidized to $\mathrm{Cu}(\mathrm{II})$ by oxygen. Hoffman ${ }^{42}$ also suggested a direct transfer of chlorine for the chlorination of aromatic compounds at the surface of fly ash. Aromatic compounds are adsorbed to the fly ash surface and chlorinated by an electrophilic aromatic substitution reaction. He suggests that iron is the chlorinating agent.

\section{Carbon Source}

The origin of carbon used for PCDD/F formation is important. ${ }^{59,60}$ Soot and sugar coal, for example, are less reactive than charcoal. Graphite produces only minor amounts of PCDD/Fs. ${ }^{60}$ The crystal lattice of graphite is probably more resistant to an attack of chlorine/oxygen than the already disturbed graphite structure of the other carbon samples. There is no correlation between the surface area of the carbon and the formation of $\mathrm{PCDD} / \mathrm{Fs},{ }^{59}$ so the variance of $\mathrm{PCDD} / \mathrm{F}$ formation from different kinds of carbon is not caused by variance in surface area. In a recent study, Eichberger et al. ${ }^{61}$ found that formation of PCDDs, PCDFs, and PCBs is correlated with the activity of the carbon.

\section{Role of Metals}

Copper is very reactive in the formation of PCDDs and PCDFs. Various metal chlorides-such as $\mathrm{MgCl}_{2}, \mathrm{ZnCl}_{2}, \mathrm{FeCl}_{2}, \mathrm{MnCl}_{2}$, $\mathrm{HgCl}_{2}, \mathrm{CdCl}_{2}, \mathrm{NiCl}_{2}, \mathrm{SnCl}_{2}, \mathrm{PbCl}_{2^{\prime}}$ and $\mathrm{CuCl}_{2}$ - have been tested for their ability to catalyze the formation of PCDD/Fs. From these metal chlorides, only $\mathrm{CuCl}_{2}$ made a significant contribution to the PCDD/F formation. ${ }^{60}$ Without metal chlorides, only trace amounts of PCDD/Fs were found. The addition of only $0.08 \% \mathrm{Cu}^{2+}$ gives rise to significant amounts of PCDD/Fs. The addition of 0.24 and $0.4 \% \mathrm{Cu}^{2+}$ gives rise to an overproportional rise in $\mathrm{PCDD} / \mathrm{F}$ formation. ${ }^{60}$ It was later found that $\mathrm{FeCl}_{3}$ can catalyze the formation of PCDD/F too, but only when it is present in high amounts. ${ }^{58}$

\section{Inhibition}

Inhibition of the formation of PCDDs and PCDFs from carbon was studied by Addink..$^{53}$ Ethylenediamine-tetra acetic acid (EDTA), nitrilo-tri-acetic acid (NTA), and $\mathrm{Na}_{2} \mathrm{~S}$ were found to inhibit the formation of PCDDs and PCDFs from carbon. $\mathrm{Na}_{2} \mathrm{~S}_{2} \mathrm{O}_{3}$ also inhibits PCDD/F formation, but less effectively. The inhibition is proposed to proceed by formation of stable complexes with transition metals, especially copper.

\section{Formation of Other Chlorinated Aromatic Compounds}

Chlorinated aromatic compounds other than PCDDs and PCDFs are formed during the municipal waste incineration process. In laboratory studies, many of those compounds are found to be formed from carbon. The most important group of compounds are chlorobenzenes, which are also dominant in municipal waste incineration. ${ }^{6}$ Besides chlorobenzenes, chloronaphthalenes, -biphenyls and -phenols, and a large number of trace compounds are formed from carbon. ${ }^{60,62-66} \mathrm{It}$ is suggested that those compounds are formed when the carbon is degraded similarly to the formation of PCDDs and PCDFs. ${ }^{60,64,65}$ Some of these products, together with the compounds present or formed in the gas stream, could act as precursor compounds for the formation of PCDDs and PCDFs.

The complexity of the formation is also found from experiments where ${ }^{18} \mathrm{O}_{2}$ is used in model experiments. ${ }^{40}$ The amount of ${ }^{18} \mathrm{O}$ found in the PCDD/Fs formed is not constant 
for all the compounds. Some compounds have relatively large amounts of ${ }^{16} \mathrm{O}$ due to oxygen, which is already present in the carbon.

\section{CONCLUSIONS}

Formation of PCDD/Fs during incineration of municipal waste is promoted by the catalytic properties of metals which are found in the waste itself. All types of carbon can serve as a carbon source. Chlorine can also be used in the different forms as it is present. Prevention of the formation can be done by poisoning the catalysts with complexing compounds. The formation of the PCDD/Fs is a complex of reactions in which chlorination of carbon and dechlorination of the innitially formed PCDD/Fs are the most important.

\section{ACKNOWLEDGMENT}

The contributions of Peter Serné, Pieter C. Slot, and Han Wever are gratefully acknowledged. This research was financed by the Technology Foundation (Stichting voor de Technische Wetenschappen), Utrecht, The Netherlands, under grant ACH03.2183.

\section{REFERENCES}

1. van den Berg, M.; de Jongh, J.; Poiger, H.; Olson, J.R. Crit. Rev. Toxicol. 1994, 24, 1-74.

2. Pluim, H.J. Ph.D. Thesis, University of Amsterdam, The Netherlands, June 1993.

3. Mackay, D.; Shiu, W.Y.; Ma, K.C. In Illustrated Handbook of Physical-Chemical Properties and Environmental Fate for Organic Chemicals; Lewis Publishers: Michigan, 1992; pp 429-560.

4. de Koning, J.; Sein, A.A.; Troost, L.M.; Bremmer, H.J. In DIOXIN'93, Organohalogen Compounds; Federal Environmental Agency: Vienna, 1993; Vol. 14,

pp 315-318.

5. Fiedler, H. In DIOXIN'93, Organohalogen Compounds; Federal Environmental Agency: Vienna, 1993; Vol. 11, pp 221-228.

6. Olie, K.; Vermeulen, P.L.; Hutzinger, O. Chemosphere 1977, 6, 455-459.

7. Lahl, U. In DIOXIN'93, Organohalogen Compounds; Federal Environmental Agency: Vienna, 1993; Vol. 11, pp 311-314.

8. Laue, G.; Herrmann, D.; Möder, M.; Herzschuh, R. In DIOXIN'93, Organohalogen Compounds; Federal Environmental Agency: Vienna, 1993; Vol. 11, pp 351-354.

9. Theisen, J.; Maulshagen, A.; Fuchs, J. Chemosphere 1993, 26, 881-896

10. Oehme, M.; Mano, S.; Bjerke, B. Chemosphere 1989, 18, 1379-1389.

11. Cleghorn, H.P.; Caton, R.B.; Groskopf, N.W.; Pilger, C.W.Chemosphere 1990 20, 1517-1524.

12. Thompson, T.S.; Clement, R.E.; Thornton, N.; Luyt, J. Chemosphere 1990, $20,1525-1532$

13. Bumb, R.R.; Crummett, W.B.; Cutie, S.S.; Gledhill, J.R.; Hummel, R.H.; Kagel, R.O.; Lamparski, L.L.; Luoma, E.V.; Miller, D.L.; Nestrick, T.J.; Shadoff, L.A.; Stehl, R.H.; Woods, J.S. Science 1980, 210, 385-390

14. Ballschmiter, K.; Buchert, H.; Niemczyk, R.; Munder, A.; Swerev, M. Chemosphere 1986, 15, 901-915.

15. Riss, A.; Aichinger, H. In DIOXIN'93, Organohalogen Compounds; Federal Environmental Agency: Vienna, 1993; Vol. 14, 341-344.

16. Hise, R.G.; Wright, B.T. Chemosphere 1990, 20, 1723-1730.

17. LaFleur, L.; Brunck, B.; McDonough, T.; Ramage, K.; Gillespie, W.; Malcolm, E. Chemosphere 1990, 20, 1731-1738.

18. Amendola, G.; Barna, D.; Blosser, R.; LaFleur, L.; McBride, A.; Thomas, F.; Tiernan, T.; Whittemore, R. Chemosphere 1989, 18, 1181-1188.

19. Clement, R.E., Tashiro, C., Suter, S., Reiner, E.; Hollinger, D. Chemosphere 1989, 18, 1189-1197.

20. Lustenhouwer, J.W.A.; Olie, K.; Hutzinger, O. Chemosphere 1980, 9, 501-522.

21. Ree, K.C.M.; Evers, E.H.G.; van den Berg, M. Toxic. Environ. Chem. 1988, 17, 171-195.

22. Jiang, K.; Chen, Y-D.; Li, L-J.; Schecter, A. In DIOXIN'93, Organohalogen Compounds; Federal Environmental Agency: Vienna, 1993; Vol. 11, pp 319-320.

23. Ehmann, J.; Birkenfeld, T.; Neumann, H. In DIOXIN'93, Organohalogen Compounds; Federal Environmental Agency: Vienna, 1993; Vol. 11, pp 329-332.
24. Christmann, W.; Klöppel, K.D.; Partscht, H.; Rotard, W. Chemosphere 1989, 18, 789-792.

25. Drechsler, W. In DIOXIN'92, Organohalogen Compounds; Finnish Institute of Occupational Health: Helsinki, 1992; Vol. 8, p 231.

26. Hasselriis, F. Waste Manag. Res. 1987, 5, 311-326.

27. Ross, R.A.; Lemay, R. Environ. Sci. Technol. 1987, 21, 1115-1118.

28. Visialli, J.R. Hazard. Waste. Manag. 1987, 37, 1451-1463.

29. Nottrodt, A.; Düwel, U.; Ballschmiter, K. Chemosphere 1990, 20, 1847-1854

30. Penner, S.S.; Li, C.P.; Richards, M.B.; Wiesenhahn, D.F. Sci. Total Environ. 1991, 104, 35-46.

31. Fängmark, I.; Strömberg, B.; Berge, N.; Rappe, C. Environ. Sci. Technol. 1994, 28, 624-629.

32. Fängmark, I.; van Bavel, B.; Marklund, S.; Rappe, C.; Strömberg, B.; Berge, N. In DIOXIN'92, Organohalogen Compounds; Finnish Institute of Occupational Health: Helsinki, 1992; Vol. 8, pp 249-252.

33. Boschi, G.; Cocheo, V.; Giannandrea, G.; Magagni, A. In DIOXIN'92, Organohalogen Compounds; Finnish Institute of Occupational Health Helsinki, 1992; Vol. 9, pp 37-38.

34. Hinton, W.S.; Lane, A.M. Chemosphere 1991, 22, 473-483.

35. Goldin, A.; Bigelow, C.; Veneman, P.L.M. Chemosphere 1992, 24, 271-280

36. Shaub, W.M.; Tsang, W. Environ. Sci. Technol. 1983, 17, 721-730.

37. Shaub, W.M.; Tsang, W. In Chlorinated Dibenzodioxins and Dibenzofurans in the total Environment II; Choudhary, G.; Keith, L.H.; Rappe, C. Eds.; Butterworth: Stoneham, MA, 1985; pp 469-487.

38. Hiraoka, M.; Fujii, T.; Kashiwabara, K.; Ieyama, K.; Kondo, M. In Dioxin '90 Organohalogen Compounds; Eco-Informa Press: Bayreuth, 1990; Vol. 3, pp 71-75.

39. Addink, R.; Olie, K. Environ. Sci. Technol. 1995, 29, 1425-1435.

40. Olie, K.; Schoonenboom, M.H.; Buijs, A.; Addink, R. In DIOXIN'95 Organohalogen Compounds; Dioxin'95 Secretariat: Edmonton, 1995; Vol. 23, pp 329-334.

41. Schooneboom, M. Ph.D. Thesis, University of Amsterdam, May 1995

42. Hoffman, R.V.; Eiceman, G.A.; Long, Y-T.; Collins, M.C.; Lu, M-Q. Environ. Sci. Technol. 1990, 24, 1635-1641.

43. Eiceman, G.A.; Hoffman, R.V.; Long, Y-T.; Collins, M.C.; Lu, M-Q. Chemosphere 1989, 18, 2193-2200.

44. Eiceman, G.A.; Hoffman, R.V.; Collins, M.C.; Long, Y-T.; Lu, M-Q. Chemosphere 1990, 21, 35-41.

45. Eiceman, G.A.; Rghei, H.O. Chemosphere 1982, 11, 833-839.

46. Rghei, H.O.; Eiceman, G.A. Chemosphere 1984, 13, 421-426.

47. Rghei, H.O.; Eiceman, G.A. Chemosphere 1985, 14, 167-171.

48. Luijk, R.; Dorland, K.; Smit, P.N.; Govers, H.A.J. In DIOXIN'92, Organohalogen Compounds; Finnish Institute of Occupational Health: Helsinki, 1992; Vol 8, pp 273-276.

49. Hagenmaier, H.; Kraft, M.; Brunner, H.; Haag, R. Environ. Sci. Technol. 1987, $21,1080-1084$

50. Vogg, H.; Metzger, M.; Stieglitz, L. Waste Manag. Res. 1987, 5, 285-294.

51. Stieglitz, L.; Vogg, H. Chemosphere 1987, 16, 1917-1922.

52. van Berkel, O.M.; Olie, K.; van den Berg, M. Intern. J. Environ. Anal. Chem. 1988. 34, 51-67.

53. Addink, R. Ph.D. Thesis, University of Amsterdam, February 1995

54. Vogg, H.; Stieglitz, L. Chemosphere 1986, 15, 1373-1378.

55. Boscak, V. Waste Manag. Res. 1993, 11, 493-505.

56. Bailleul, G.; Bratzler, K.; Herbert, W.; Vollmer, W. In Aktive Kohle und ihre Industrielle Verwendung; Ferdinand Enke Verlag: Stuttgart, 1953; pp 9-14.

57. Griffin, R.D. Chemosphere 1986, 15, 1987-1990.

58. Stieglitz, L.; Vogg, H.; Zwick, G.; Beck, J.; Bautz, H. Chemosphere 1990, 23 1255-1264.

59. Stieglitz, L.; Zwick, G.; Beck, J.; Bautz, H.; Roth, W. Chemosphere 1990, 20 , 1953-1958.

60. Stieglitz, L.; Zwick, G.; Beck, J.; Roth, W.; Vogg, H. Chemosphere 1989, 18 1219-1226.

61. Eichberger, M.; Stieglitz, L. In DIOXIN'94, Organohalogen Compounds; Kyoto University: Kyoto, 1994; Vol. 20, pp 385-390.

62. Jay, K.; Stieglitz, L. Chemosphere 1991, 22, 987-996.

63. Schwarz, G.; Stieglitz, L.; Roth, W. DIOXIN'90, Organohalogen Compounds, Ecoinforma Press: Bayreuth, 1990; Vol. 3, pp 169-172.

64. Stieglitz, L.; Zwick, G.; Beck, J.; Bautz, H.; Roth, W. Chemosphere 1989, 19 283-290.

65. Stieglitz, L.; Eichberger, M.; Schleihauf, J.; Beck, J.; Zwick, G.; Will, R. Chemosphere 1993, 27, 343-350.

66. Milligan, M.S.; Altwicker, E.R. Environ. Sci. Technol. 1993, 27, 1595-1601.

\section{About the Authors}

Kees Olie is with the Department of Environmental and Toxicological Chemistry, Faculty of Chemistry, Amsterdam Research Institute for Substances in Ecosystems, University of Amsterdam, Nieuwe Achtergracht 166, 1018 WV, The Netherlands. Mirjam Schoonenboom and Ruud Addink prepared their theses at this University. 